\title{
STRATEGI PERPUSTAKAAN TERHADAP PENINGKATAN MINAT KUNJUNG PEMUSTAKA DI PERPUSTAKAAN UIN ALAUDDIN MAKASSAR
}

\author{
Andi Ibrahim*
}

Pengutipan: Ibrahim. A. (2017). Starategi perpustakaan terhadap peningkatan minat kunjung pemustaka di Perpustakaan UIN Alauddin Makassar. Khizanah al-Hikmah : Jurnal Ilmu Perpustakaan, Informasi, dan Kearsipan. 5(2), 207-221.

DOI: https://doi.org/10.24252/kah.v5i2a8

*Jurusan Ilmu Perpustakaan UIN Alauddin Makassar

andiibe88@yahoo.co.id

\begin{abstract}
ABSTRAK
Penelitian ini fokus pada strategi perpustakaan terhadap peningkatan minat kunjung pemustaka di perpustakaan Universitas Islam Negeri Alauddin Makassar. Rumusan masalah dalam penelitian ini adalah bagaimana strategi perpustakaan dalam meningkatkan minat kunjung pemustaka di perpustakaan UIN Alauddin Makassar. Tujuan dari penelitian ini untuk mengetahui bagaimana strategi perpustakaan terhadap peningkatan minat kunjung pemustaka di perpustakaan Universitas Islam Negeri UIN Alauddin Makassar dari segi aspek pelayanan pemustaka serta dari aspek sarana dan prasarana. Penelitian deskriptif ini menggunakan pendekatan analisis data kualitatif purposive yakni data yang diperoleh dari sumber data (informan) dapat digambarkan secara deskriktif hingga data tersebut sampai ke titik jenuh. Model analisis kualitatif lebih mengutamakan pada content analisis yang tertuju pada pendalaman dan penghayatan terhadap makna data-data yang dikaji, dengan pendalaman pemikiran terhadap data-data tersebut memungkinkan hasil penelitian yang dicapai memadai. Strategi Perpustakaan dalam meningkatkan minat kunjung pemustaka dari aspek pelayanan ialah dititikberatkan pada kehandalan, daya tanggap, jaminan mutu pelayanan, dan rasa empati terhadap pemustaka. sedangkan dari aspek sarana dan prasarana ialah Penempatan gedung perpustakaan yang strategis dan mudah dijangkau oleh pemustaka, Penataan rak (rak buku, meja, kursi baca) strategis dan teratur, Menyediakan koleksi (koleksi buku umum, referensi, jurnal) lengkap sesuai kebutuhan pemustaka, Menyediakan fasilitas (rak buku, rak majalah, kabinet gambar, lemari atau kabinet catalog, papan pengumuman, meja baca, kusi, papan display, OPAC) lengkap dan memadai, Menyediakan jaringan internet yang mendukung pemustaka untuk mengakses informasi.
\end{abstract}

Kata kunci: Strategi perpustakaan, Minat kunjung, pemustaka

\section{ABSTRACT}

The study is aimed to measure how UIN Alauddin library increased the number of library visits particularly in terms of library services and library facilities and infrastructures. This is a descriptive research that uses purposive analysis approach in order to elaborately explain the findings. The data were gathered from all librarians in UIN library. In addition, some supported reports are gathered as well. From library services aspect, the study focuses on reliability, responsiveness, service quality, and empathy. Meanwhile, from facilities and infrastructures, the study figured out the location of the library within the campus, library shelves, library information spots, reading areas, library catalogs, and so on.

Key words: Library strategy, library visit, library users 


\section{PENDAHULUAN}

\section{a. Latar Belakang}

Perpustakaan universitas dalam kegiatannya, selain pemberian layanan informasi terhadap seluruh pemustaka (pengguna) perpustakaan universitas juga dituntut untuk dapat memperhatikan akan kebutuhan bahan pustaka yang diperlukan oleh pengguna perpustakaan itu sendiri, sehingga dapat dimanfaatkan untuk tujuan pembelajaran dan penambahan ilmu pengetahuan bagi pengguna perpustakaan, dan fungsi pendidikan mendapat porsi yang lebih besar dalam perpustakaan universitas.

Salah satu komponen yang menentukan keberhasilan layanan perpustakaan adalah sumber daya manusia. Sumber daya manusia di perpustakaan menurut Undang-undang Nomor 43 Tahun 2007 tentang Perpustakaan Pasal 29 terdiri atas pustakawan dan tenaga teknis pustakawan. Tenaga teknis pustakawan adalah tenaga non pustakawan yang secara teknis mendukung pelaksanaan, misalnya tenaga teknis komputer, tenaga teknis audio visual, dan tenaga teknis ketatausahaan, sedangkan yang dimaksud pustakawan adalah "seseorang yang memiliki kapabilitas, integritas, dan kompetensi di bidang perpustakaan". (Republik Indonesia, 2007: 4).

Pengguna sebagai titik sentral orientasi perpustakaan, maka di sinilah peran perpustakaan dan para pustakawan sebagai pengelola untuk lebih profesional, berkualitas, berpengetahuan, berketerampilan yang tinggi serta memiliki pemikiran yang cemerlang dalam menyusun strategi untuk menarik minat pemustaka untuk mengunjungi perpustakaan, karena masalah yang lebih serius sebenarnya bukan lagi pada pemetaan atau segmentasi kelompok sasaran, tetapi bagaimana strategi yang akan diterapkan sehingga mampu mengidentifikasi kebutuhan informasi yang diinginkan pemustaka, karena kebutuhan dan minat terhadap informasi serta karakter pengguna di perpustakaan sangat beragam.

Pustakawan adalah faktor penggerak sebuah perpustakaan, jika pustakawannya kreatif tentulah perpustakaan tersebut akan selalu berinovasi mengikuti tuntutan zaman. Pustakawan sekarang ini harus selalu dituntut memiliki strategi-strategi khusus dan cerdas dalam menjalankan manajemen perpustakaan. Strategistrategi tersebut dapat berupa pelayanannya yang berbeda dari perpustakaan lain, dekorasi gedung yang menarik, serta sarana dan prasarana atau fasilitas yang terkini atau up-to-date dengan zaman yang sedang trend, dengan adanya strategi ini diharapkan menarik minat masyarakat berkunjung di perpustakaan serta menjadikan perpustakaan sebagai tempat penting dan wajib untuk dikunjungi dalam kesehariannya.

Sesuai dengan pengamatan serta data sementara yang diperoleh dari interview dengan beberapa mahasiswa yang sering berkunjung ke perpustakaan UIN Alauddin Makassar terdapat kendalakendala yang ditemukan yaitu sarana dan prasarana yang masih perlu ditambah dikarenakan banyak buku-buku yang dibutuhkan oleh mahasiswa, tetapi belum tersedia di perpustakaan. Di sinilah perlunya perpustakaan meningkatkan strategi terhadap minat kunjung pemustaka.

Berdasarkan latar belakang di atas, maka peneliti tertarik untuk mencari tahu strategi perpustakaan UIN Alauddin 
Makassar terhapat peningkatan minat kunjung pemustakanya.

\section{b. Rumusan Masalah}

Berdasarkan uraian latar belakang tersebut di atas, maka peneliti dapat merumuskan permasalahan dalam penelitian ini sebagai berikut: "Bagaimana Strategi Perpustakaan Terhadap Peningkatan Minat Kunjung Pemustaka di Perpustakaan UIN Alauddin Makassar".

Dari rumusan masalah tersebut dapat dijabarkan beberapa pertanyaan penelitian, sebagai berikut:

1) Bagaimanakah strategi perpustakaan terhadap peningkatan minat kunjung pemustaka di perpustakaan UIN Alauddin Makassar ditinjau dari aspek pelayanan pemustaka?

2) Bagaimanakah strategi perpustakaan terhadap peningkatan minat kunjung pemustaka di perpustakaan UIN Alauddin Makassar dari aspek sarana dan prasarana?

\section{KAJIAN PUSTAKA}

\section{a. Strategi Perpustakaan}

Suatu perpustakaan akan dapat memberi pelayanan informasi yang memuaskan apabila dilengkapi dengan sarana dan prasarana yang memadai, tak kalah pentingnya adalah adanya tenaga pustakawan yang mempunyai kemampuan professional dalam memberikan layanan perpustakaan.

Pustakawan sebagai komponen tenaga kerja di perpustakaan UIN Alauddin Makassar secara dinamis dalam pelaksanaan seluruh kegiatan kerja, sehingga perpustakaan dapat berfungsi sesuai dengan peranannya. Karena perannya yang dinamis, kondisi tenaga kerja di perpustakaan sangat menentukan tinggi rendahnya pelayanan informasi yang dibutuhkan sehingga secara langsung dapat mempengaruhi tingkat kunjungan.

Pengertian strategi adalah rencana yang cermat mengenai kegiatan untuk mencapai sasaran khusus (Departemen Pendidikan dan Kebudayaan, 2008: 2051).

Kesimpulan dari definisi strategi perpustakaan yaitu rencana perpustakaan dalam hal ini para pustakawan yang telah dipikirkan secara bersama-sama secara cermat mengenai kegiatan yang akan dilakukan kedepannya untuk mencapai sasaran khusus.

\section{b. Minat Kunjungan}

Menurut (Sutarno NS, 2003:27) minat seseorang terhadap sesuatu adalah kecenderungan hati yang tinggi, gairah atau keinginan seseorang tersebut terhadap sesuatu. Minat kunjungan seseorang dapat diartikan sebagai kecenderungan hati yang tinggi untuk datang ke suatu tempat tertentu, dan dalam konteks perpustakaan tempat yang dimaksud adalah kunjungan ke perpustakaan dengan tujuan untuk mencari informasi dan ilmu pengetahuan di perpustakaan.

Sedangkan Menurut (Jefkins, 1997:241) dalam kegiatan publikasi suatu produk, untuk menimbulkan suatu efek yang baik dari konsumen maka penting memperhatikan elemen-elemen dalam sebuah rumus yang dikenal dengan AIDCA yang terdiri dari perhatian (attention), ketertarikan (interest), keinginan (desire), keyakinan (conviction), dan tindakan (action). 
Berkunjung berasal dari kata kunjung yang mendapat awalan ber- sehingga menjadi berkunjung yang bermakna mendatangi untuk menengok, menjumpai (KBBI, 2005: 476). Menurut (Dahlan, 2006:1) beberapa hal yang membuat orang atau mendorong pengguna/pemustaka betah dan ingin berkunjung ke perpustakaan dikarenakan:

$\checkmark$ Rasa nyaman,

$\checkmark$ Keadaan lingkungan fisik yang memadai,

$\checkmark$ Keadaan lingkungan sosial yang kondusif,

$\checkmark$ Layanan yang diberikan perpustakaan.

Menurut Marmoatmojo

(1999:23), seperti: lomba pidato, lomba membaca puisi, lomba menggambar dan sebagainya dengan mengadakan berbagai perlombaan di perpustakaan dapat mengundang pemustaka untuk berkunjung ke perpustakaan.

Minat kunjung merupakan kecenderungan jiwa yang mendorong seseorang mengunjungi dan memanfaatkan perpustakaan. Minat kunjung ditunjukkan dengan keinginan yang kuat untuk datang dan memanfaatkan fasilitas yang disediakan terutama membaca koleksi perpustakaan. Minat kunjung sangat erat kaitannya dengan minat baca dan keterampilan membaca (Darmono, 2001:182).

Dari beberapa defenisi tersebut, minat kunjung menurut peneliti adalah kecenderungan jiwa yang mendorong seseorang memanfaatkan fasilitas tempat yang dikunjungi. Minat kunjung adalah menghadirkan keinginan dari dalam jiwa untuk hadir pada tempat yang menarik dan diinginkan. Minat berkunjung merupakan cerminan dari keinginan seseorang untuk mendatangi suatu tempat disebabkan oleh adanya rangsangan dari luar yang mempengaruhi atau menarik minat orang tersebut.

\section{c. Strategi Perpustakaan untuk Meningkatkan Minat Kunjung Pemustaka}

Perpustakaan perguruan tinggi sebagai suatu unit pelaksana teknis, mengembangkan tugas mendukung tujuan lembaga induknya, yaitu memberikan layanan informasi kepada sivitas akademika yang relevan dengan program Tridharma perguruan tinggi yaitu pengajaran, penelitian dan pengabdian kepada masyarakat.

Untuk mendukung tercapainya tujuan tersebut, perpustakaan perguruan tinggi melaksanakan fungsinya sebagai pusat pendidikan, pusat informasi, pusat penelitian dan pusat rekreasi. Dalam melaksanakan fungsi-fungsi tersebut, perpustakaan Perguruan Tinggi perlu menghimpun, mengelola dan menyajikan bahan pustaka sebagai sumber informasi agar dapat dimanfaatkan secara maksimal oleh pemakainya sehingga dapat memperluas cakrawala pandang para pemakai jasa perpustakan.

Ziethaml, Bery, dan Parasuraman (Tjiptono, 1997: 26) mengungkapkan bahwa untuk mengetahui kualitas pelayanan yang dirasakan secara nyata oleh konsumen, ada 5 indikator ukuran kepuasan, yaitu:

1) Bukti langsung (tangibles): kualitas pelayanan yang berupa fasilitas fisik, perlengkapan, pegawai, dan sarana komunikasi,

2) Kehandalan (reliability): kemampuan memberikan pelayanan yang dijanjikan dengan segera dan memuaskan,

3) Daya tanggap (responsiveness): keinginan para staf untuk membantu 
para pelanggan dan memberikan pelayanan dengan tanggap,

4) Jaminan (assurance): mencakup kemampuan, kesopanan, dan sifat dapat dipercaya yang dimiliki para staf, bebas dari bahaya resiko atau keraguraguan.

5) Empati (emphaty): meliputi kemudahan dalam melakukan hubungan komunikasi yang baik, dan memahami kebutuhan para pelanggan.

Menurut Larasati 1991: 55, bahwa fungsi perpustakaan adalah berusaha memberikan pelayanan kepada lembaga pendidikan agar kegiatan belajar mengajar yang digariskan dalam kurikulum dapat berjalan dengan lancar. Sesuai dengan maksud itulah maka perpustakaan harus dapat menyediakan segala keperluan peralatan yang menunjang pengajaran yang dilaksanakan di lembaga pendidikan baik berupa bukubuku pegangan, buku-buku pelengkap dan sebagainya maupun bahan-bahan pengajaran lainnya seperti alat peraga.

Selain koleksi, fasilitas lain perpustakaan yang merupakan penting adalah segala perkakas yang digunakan dalam penyelenggaraan perpustakaan. Perlengkapan atau fasilitas ini meliputi rak buku, rak surat kabar, rak majalah, kabinet gambar, meja sirkulasi, lemari atau kabinet katalog, papan display, papan pengumuman, meja baca dan perlengkapan lainnya yang digunakan secara tidak langsung.

Selain kelengkapan fasilitas perpustakaan tersebut, yang perlu diperhatikan adalah penataan ruangan perpustakaan sehingga memberikan kelancaran bagi pengelola dalam menyelenggarakan perpustakaan, juga pemakai perpustakaan pada umumnya. Dengan demikian maka keadaan gedung serta fasilitas perpustakaan ini juga turut menunjang terhadap kelancaran aktivitas belajar mahasiswa karena mahasiswa mudah untuk memanfaatkannya dengan baik.

Dengan demikian dapat ditarik kesimpulan bahwa sarana dan prasarana perpustakaan adalah keseluruhan fasilitas yang ada untuk menunjang pelaksanaan tugas pokok pada Perpustakaan.

\section{METODOLOGI PENELITIAN}

\section{a. Jenis Penelitian}

Penelitian yang digunakan adalah jenis penelitian deskriptif (Descrictive Research) dengan pendekatan analisis data kualitatif purposive sehingga data yang diperoleh dari sumber data (informan) dapat digambarkan secara deskriktif hingga data tersebut sampai ke titik jenuh. Model analisis kualitatif lebih mengutamakan pada content analisis yang tertuju pada pendalaman dan penghayatan terhadap makna data-data yang dikaji, dengan pendalaman pemikiran terhadap datadata tersebut memungkinkan hasil penelitian yang dicapai memadai. Selain itu, penelitian kualitatif secara prosedur penelitian akan menghasilkan data deskriptif berupa kata tertulis atau lisan dari sumber-sumber yang berhubungan dengan penelitian.

\section{b. Waktu dan Tempat Penelitian}

Penelitian ini dilakukan dalam jangka waktu lima bulan, yakni mulai tanggal 10 Maret 2015 sampai dengan 11 Agustus 2015. Penelitian ini beralamat di Jalan H. M. Yasin Limpo No. 63 Makassar dan lokasi penelitian tepatnya berada di Perpustakaan Pusat UIN Alauddin Makassar. 


\section{c. Informan Penelitian}

Dalam Undang-Undang Nomor 43 Tahun 2007 Bab VIII Pasal 29 ayat 1 sampai ayat 3 dijelaskan bahwa tenaga perpustakaan adalah sebagai berikut:

1) Tenaga perpustakaan terdiri atas pustakawan dan tenaga teknis perpustakaan.

2) Pustakawan sebagaimana dimaksud pada ayat (1) harus memenuhi kualifikasi sesuai dengan standar nasional perpustakaan.

3) Tugas tenaga teknis perpustakaan sebagaimana dimaksud pada ayat (1) dapat dirangkap oleh pustakawan sesuai dengan kondisi perpustakaan yang bersangkutan.

Tabel 1. Informan penelitian

\begin{tabular}{|c|l|c|}
\hline No. & \multicolumn{1}{|c|}{ Nama } & Jabatan \\
\hline 1 & Himayah, S.Ag.,SS.,MIMS & $\begin{array}{c}\text { Kepala } \\
\text { Perpustakaan }\end{array}$ \\
\hline 2 & Idham, S.Pd.I & $\begin{array}{c}\text { Kepala Bagian } \\
\text { Sirkulasi }\end{array}$ \\
\hline 3 & Ely Kamariah & $\begin{array}{c}\text { Koordinator } \\
\text { Shelfing }\end{array}$ \\
\hline 4 & Asniar, S.Ag & $\begin{array}{c}\text { Koordinator } \\
\text { Bagian } \\
\text { Pengembangan } \\
\text { Koleksi }\end{array}$ \\
\hline 5 & $\begin{array}{l}\text { Fatmawati, S.Hum., } \\
\text { M.Hum }\end{array}$ & $\begin{array}{c}\text { Koordinator } \\
\text { Bagian Pengolahan } \\
\text { Bahan Pustaka }\end{array}$ \\
\hline 6 & $\begin{array}{l}\text { Andi Mansyur, S.Hum., } \\
\text { MM }\end{array}$ & $\begin{array}{c}\text { Koordinator } \\
\text { Teknologi dan } \\
\text { informasi } \\
\text { Perpustakaan }\end{array}$ \\
\hline
\end{tabular}

(Sumber Data : perpustakaan UIN Alauddin Makassar, 2015)

\section{d. Teknik Pengumpulan Data}

Teknik pengumpulan data yang digunakan dalam penelitian ini adalah:
1) Wawancara

Jenis wawancara yang digunakan dalam penelitian ini adalah wawancara semiterstruktur (semistructure interview). Jenis wawancara ini sudah termasuk dalam katgori in-dept interview, di mana dalam pelaksanaannya lebih bebas bila dibandingkan dengan wawancara terstruktur. Tujuan dari wawancara jenis ini adalah untuk menemukan permasalahan secara lebih terbuka, di mana pihak yang diajak wawancara (informan), diminta pendapat dan ideidenya.

Adapun beberapa pertanyaan yang akan diajukan kepada informan pada saat wawancara yaitu terkait dengan jabatan, tugas, kegiatan pustakawan setiap hari, serta peranan atau tindakan yang dilakukan pustakawan dalam meningkatkan minat kunjung pemustaka dalam di Perpustakaan UIN Alauddin Makassar. Hal ini juga dianggap penting karena berkaitan dengan pokok permasalahan yang akan diteliti dan juga akan mempermudah peneliti nantinya dalam penyusunan hasil penelitian.

2) Observasi

Jenis observasi yang digunakan dalam penelitian ini adalah observasi partisipasi pasif (passive participation). Dalam observasi ini, peneliti datang di tempat kegiatan orang yang diamati, tetapi tidak terlibat dalam kegiatan tersebut. (Sugiyono, 2013: 227).

Adapun teknik pengumpulan data yang digunakan dalam observasi ini yaitu dengan cara melakukan pengamatan kepada pustakawan terkait dengan fungsi, tugas, atau kegiatan-kegiatan yang dilakukan pustakawan dalam setiap harinya (sesuai dengan jangka waktu penelitian) yang telah ditentukan kepada 
peneliti di perpustakaan tersebut, apakah dengan kegiatan-kegiatan yang dilakukannya tersebut dapat menumbuhkan minat kunjung pemustaka ataukah justru sebaliknya. Hal ini pun sangat penting dan perlu untuk dilakukan oleh peneliti karena sangat berkaitan dengan pokok permasalahan yang diteliti.

\section{3) Dokumentasi}

Dokumentasi yaitu digunakan untuk memperoleh data menyangkut suasana pengunjung, koleksi, fasilitas, gedung atau ruangan perpustakaan, serta kegiatan-kegiatan pustakawan di Perpustakaan UIN Alauddin Makassar.

\section{4) Instrumen Penelitian}

Dalam penelitian kualitatif, yang menjadi instrumen atau alat penelitian adalah peneliti itu sendiri. Untuk itu, peneliti sebagai instrumen juga harus "divalidasi" seberapa jauh peneliti kualitatif siap melakukan penelitian yang selanjutnya terjun ke lapangan. Validasi terhadap peneliti sebagai instrumen meliputi validasi terhadap pemahaman metode penelitian kualitatif, penguasaan wawasan terhadap bidang yang diteliti, kesiapan peneliti untuk memasuki objek penelitian, baik secara akademik maupun logistiknya. Yang melakukan validasi adalah peneliti sendiri, melalui evaluasi diri seberapa jauh pemahaman terhadap bidang yang diteliti, serta kesiapan dan bekal memasuki lapangan (Sugiyono, 2013: 222).

\section{5) Teknik Analisis Data}

Teknik analisa data yang peneliti gunakan yaitu data kualitatif yaitu hasil dari wawancara kepada informan yang diberikan penjelasan secukupnya kemudian diberikan kesimpulan.
6) Uji Keabsahan Hasil Penelitian

Menurut Bungin (2007:261-262), penelitian kualitatif menghadapi persoalan penting mengenai pengujian keabsahan hasil penelitian. Banyak hasil penelitian kualitatif diragukan kebenarannya karena beberapa hal diantaranya seperti;

Subjektivitas peneliti merupakan hal yang dominan dalam penelitian kualitatif;

$\checkmark$ Alat penelitian yang diandalkan adalah wawancara dan observasi (apapun bentuknya) mengandung banyak kelemahan ketika dilakukan secara terbuka dan apalagi tanpa control (dalam observasi partisipasi);

Sumber data kualitatif yang kurang creadible akan memengaruhi hasil akurasi penelitian.

\section{HASIL PENELITIAN DAN PEMBAHASAN}

Strategi yang dilakukan perpustakaan dalam meningkatkan minat kunjung pemustaka di perpustakaan UIN Alauddin Makassar yaitu sebagai berikut:

\section{a. Strategi Perpustakaan dalam Layanan}

1) Pustakawan memberikan pelayanan yang dijanjikan dengan segera dan memuaskan,

2) Pustakawan membantu pemustaka dalam menemukan koleksi yang diinginkan,

3) Pustakawan berkomunikasi dengan baik terhadap pemustaka yang mengalami kesulitan,

4) Pustakawan memahami kebutuhan pemustaka terhadap informasi yang diinginkan,

5) Pustakawan melayani pemustaka dengan ramah dan sabar. 
b. Strategi Perpustakaan dalam Sarana dan Prasarana

1) Letak gedung perpustakaan yang strategis dan mudah dijangkau oleh pemustaka,

2) Penataan rak (rak buku, meja, kursi baca) strategis dan teratur,

3) Kelengkapan koleksi (koleksi buku umum, referensi, jurnal) lengkap sesuai kebutuhan pemustaka,

4) Kelengkapan fasilitas (rak buku, rak majalah, kabinet gambar, lemari atau kabinet catalog, papan pengumuman, meja baca, kusi, papan display, OPAC) lengkap dan memadai,

5) Tersedia jaringan intenet yang mendukung pemustaka untuk mengakses informasi.

Strategi Pengolahan di UPT Perpustakaan UIN Alauddin Makassar dikelola 2 bagian dimulai dari :

\section{a) Bagian Pengembangan Koleksi}

Pada bagian pengembangan koleksi bekerja setiap ada buku yang baru masuk ke Perpustakaan meregistrasi buku yang baru masuk kedalam buku induk sebelum buku diserahkan untuk diolah. Bagian pengembangan koleksi bertanggung jawab dalam hal peningkatan mutu koleksi yang ada di perpustakaan yakni dengan menyediakan koleksi yang dibutuhkan oleh civitas akademika.

\section{b) Bagian Pengolahan Bahan Pustaka}

Pada bagian pengolahan, Setiap buku yang sudah diregistrasi pada bagian pengembangan koleksi buku tersebut segera di kelolah oleh petugas bagian pengolahan mulai dari memberikan stempel kepemilikan, inventarisasi, mengklasifikasi bahan pustaka, katalog elektronik dan mengimput kedalam worksheet.
Seorang pustakawan yang ulet akan memenuhi kebutuhan pemustakanya dengan cara menambah koleksi yang dibutuhkan oleh mahasiswa dan dosen yang berkunjung di perpustakaan sebab dengan banyaknya koleksi yang tersedia di perpustakaan maka pemustaka akan termotivasi berkunjung ke perpustakaan tersebut, jika semakin banyak pemustaka yang berkunjung ke perpustakaan maka tujuan perpustakaan sebagai penyedia jasa informasi dan lembaga pendidikan sepanjang hayat akan semakin terwujud.

Dari hasil penelitian yang dilakukan oleh penulis, maka sistem pengolahan bahan pustaka di UPT Perpustakaan Universitas Islam Negeri Alauddin Makassar dapat dikelompokan berdasarkan hasil sebagai berikut:

\section{a. Strategi Pustakawan dalam Layanan Pemustaka pada Perpustakaan Universitas Islam Negeri Alauddin Makassar}

Ziethaml, Bery, dan Parasuraman (Tjiptono, 1997:26) mengungkapkan bahwa untuk mengetahui kualitas pelayanan yang dirasakan secara nyata oleh konsumen, ada 4 indikator ukuran kepuasan, yaitu:

1) Kehandalan (reliability): kemampuan memberikan pelayanan yang dijanjikan dengan segera dan memuaskan,

2) Daya tanggap (responsiveness): keinginan para staf untuk membantu para pelanggan dan memberikan pelayanan dengan tanggap,

3) Jaminan (assurance): mencakup kemampuan, kesopanan, dan sifat dapat dipercaya yang dimiliki para staf, bebas dari bahaya resiko atau keraguraguan.

4) Empati (emphaty): meliputi kemudahan dalam melakukan hubungan 
komunikasi yang baik, dan memahami kebutuhan para pelanggan.

Dengan mengacu pada konsep di atas, maka hasil penelitian yang peneliti dapatkan dalam hasil wawancara dengan para informan adalah sebagai berikut:

Berdasarkan wawancara dengan Kepala Perpustakaan Universitas Islam Negeri Alauddin Makassar pada tanggal 11 Mei 2015, dalam hal pelayanan di perpustakaan, beliau menyatakan bahwa:

"Tenaga pustakawan yang kami miliki disini sangat tanggap dalam melayani pemustaka, selalu memperhatikan kebutuhan pemustaka dan membantu mereka dalam penelusuran informasi. Hal itulah yang kami selalu ingatkan pada para pustakawan terutama yang bertugas pada bagian sirkulasi yang senantiasa berinteraksi secara langsung dengan pemustaka, bahwa utamakanlah sifat menghargai pemustaka, ramah pada mereka, dan memperhatikan kebutuhan mereka akan informasi agar mereka merasa nyaman berada di perpustakaan."

Selanjutnya, wawancara dengan koordinator bagian sirkulasi UPT Perpustakaan UIN Alauddin Makassar pada tanggal 11 Mei 2015, dalam hal pelayanan di perpustakaan, beliau menyatakan bahwa:

"Semboyan 3 S selalu kami pertahankan, senyum, sapa, dan sopan, demi kenyamanan pemustaka. Kami pantang memasang wajah cemberut dalam keadaan dan situasi apapun terutama pada bagian sirkulasi. Kalau kita bermuka masam, maka tentu yang terjadi adalah kedidaknyamanan pemustaka di perpustakaan, dan kami tentu akan kehilangan pengunjung perpustakaan". (Idham, koordinator bagian sirkulasi)
Selanjutnya, wawancara dengan koordinator bagian shelfing perpustakaan Universitas Islam Negeri Alauddin Makassar pada tanggal 11 Mei 2015, dalam hal pelayanan di perpustakaan, beliau menyatakan bahwa:

"Untuk menarik minat kunjungan dan meningkatkan kualitas layanan kepada pemustaka di perpustakaan UIN Alauddin Makassar, saya selaku koordinator bagian shelfing, berusaha untuk selalu menjaga kerapian, kebersihan, dan penataan ruang yang menarik, estetis, dan nyaman. (Ely Kamariah, koordinator shelfing).

Selanjutnya, wawancara dengan koordinator bagian pengembangan koleksi perpustakaan Universitas Islam Negeri Alauddin Makassar pada tanggal 11 Mei 2015, dalam hal pelayanan di perpustakaan, beliau menyatakan bahwa:

"Untuk meningkatkan kualitas pelayanan di perpustakaan UIN Alauddin Makassar, kami selalu berusaha memenuhi kebutuhan informasi kepada para pemustaka, berusaha memahami koleksi yang paling mereka butuhkan dan menyediakannya". (Asniar, koordinator bagian pengembangan koleksi).

Selanjutnya, wawancara dengan koordinator bagian pengolahan koleksi perpustakaan Universitas Islam Negeri Alauddin Makassar pada tanggal 11 Mei 2015, dalam hal pelayanan di perpustakaan, beliau menyatakan bahwa:

"Upaya meningkatkan kualitas layanan perpustakaan, kami selalu mengikuti standar pengolahan sesuai aturan DDC, agar pemustakan dapat dengan mudah memperoleh informasi yang mereka butuhkan, Pengolahan bahan pustaka di UPT Pusat perpustakaan UIN Alauddin Makassar menggunakan tajuk subyek perpustakaan nasional dan DDC" alur 
kerja yang dilakukan dalam pengolahan bahan pustaka yaitu dengan beberapa tahapan yaitu stempel registrasi, stempel kepemilikan, stempel punggung, registrasi buku, katalogisasi worksheet, labeling buku, barcode, inputing data base slims." Bahan pustaka yang dikatalog dan diklasifikasi setiap tahunnya di UPT Perpustakaa UIN Alauddin Makassar kurang lebih 3000 eksemplar" "alat yang digunakan pustakawan dalam proses pengolahan bahan pustaka yaitu Stempel, buku induk, DDC, Tajuk subyek umum, tajuk subyek islam dan sistem klasifikasi islam, tajuk subyek perpustakaan nasional dan work sheet (lembar kerja)"Katalog elektronik dibuat dengan cara mengisi worksheet terlebih dahulu didalam worksheet data yang akan di isi lebih lengkap yaitu judul, pengarang, penerbit, tempat terbit, tahun terbit, ISBN, Halaman, jenis bahasa, jenis koleksi, No. Registrasi, dan nomor klasifikasi"(Fatmawati, koordinator bagian pengolahan).

Selanjutnya, wawancara dengan koordinator bagian Informasi dan komunikasi perpustakaan Universitas Islam Negeri Alauddin Makassar pada tanggal 11 Mei 2015, dalam hal pelayanan di perpustakaan, beliau menyatakan bahwa:

"Dalam bidang teknologi informasi, kami senantiasa berupaya terus mengembangkan sistem temu balik informasi agar semakin lancar, sistem yang kami gunakan sekarang ini ialah OPAC yang memudahkan pemustaka mencari literatur yang mereka butuhkan. Sistem alih media dari media cetak ke digital untuk koleksi tertentu juga terus kami lakukan untuk memudahkan proses pencarian informasi apabila dibutuhkan" (Andi Mansyur, koordinator bagian Teknologi Informasi).

Berdasarkan pernyataan dari keenam informan di atas, maka peneliti menarik kesimpulan berdasarkan urutan informan sebagai berikut:
1. Menurut kepala perpustakaan bahwa, UPT perpustakaan UIN Alauddin Makassar memiliki tenaga pustakawan yang handal, senantiasa memperhatikan kebutuhan pemustaka dan membantu mereka dalam penelusuran informasi. Para pustakawan di UPT Perpustakaan UIN Alauddin Makassar menjalankan proses pelayanan berbasis pengguna, yakni berinteraksi dengan baik dan mengutamakan kepuasan pemustaka.

2. Menurut koordinator bagian sirkulasi, bahwa pelayanan di perpustakaan UIN Alauddin Makassar memperhatikan keramahan dan perhatian kepada pemustaka, cara berkomunikasi dan memahami kebutuhan pengguna.

3. Menurut koordinator bagian shelfing, bahwa dalam meningkatkan pelayanan yang baik, maka perpustakaan UIN Alauddin Makassar memperhatikan kebersihan, kerapian, tata ruang, dan tidak monoton serta membosankan jika berada dalam ruangan dan menyediakan ruangan yang estetis danm nyaman.

4. Menurut koordinator bagian pengembangan koleksi, perpustakaan UIN Alauddin Makassar memperhatikan kebutuhan koleksi para pemustaka, serta berusaha untuk menyediakan koleksi yang dibutuhkan.

5. Menurut koordinator bagian pengolahan, menyatakan bahwa untuk menjaga dan meningkatkan pelayanan di perpustakaan UIN Alauddin Makassar, maka pengolahan bahan pustaka harus sesuai dengan aturan DDC (dewey decimal classification) agar penataan koleksi di perpustakaan mudah ditemukan oleh pemustaka.

6. Menurut koordinator bagian informasi dan teknologi, perpustakaan UIN Alauddin Makassar menyediakan sistem temu balik informasi yang sistematis dan efisien. 
Dengan memperhatikan pernyataan dari beberapa informan, maka peneliti menarik sebuah kesimpulan bahwa strategi yang digunakan dalam meningkatkan minat kunjungan pemustaka di perpustakaan telah memenuhi beberapa kriteria, khususnya dari segi pelayanan yang ideal bagi pemustaka. adapun kriteria tersebut sebagaimana pendapat dari Ziethaml, Bery, dan Parasuraman diantaranya ialah:

\section{a. Kehandalan (reliability)}

Kehandalan dalam hal ini pustakawan yang ada diperpustakaan UIN Alauddin Makassar memiliki kehandalan dalam melayani pemustaka dan senantiasa berupaya untuk selalu memberikan pelayanan yang sesuai dengan kebijakan dan aturan yang berlaku.

\section{b. Daya Tanggap (responsiveness)}

Dalam hal ini, pustakawan pada perpustakaan pusat UIN Alauddin Makassar memiliki daya tanggap yang baik dalam melayani pemustaka. Mereka senantiasa berusaha memberikan pelayanan yang bermutu sesuai dengan kemampuan yang mereka miliki. Para pustakawan membantu pemustaka yang kesulitan mencari literatur yang mereka butuhkan.

Dalam hal ini, pustakawan pada perpustakaan pusat UIN Alauddin Makassar dapat dipercaya, jujur dan memiliki wawasan intelektual sehingga mudah memberikan informasi yang dibutuhkan oleh pemustaka.

\section{c. Empati (Empathy)}

Dalam hal ini, pustakawan pada perpustakaan UIN Alauddin Makassar memiliki kemudahan dalam melakukan hubungan komunikasi yang baik, dan memahami kebutuhan para pemustaka.

Olehnya itu, kesimpulan akhir dari peneliti mengenai strategi yang diterapkan pada perpustakaan UIN Alauddin Makassar dalam hal pelayanan dititikberatkan pada kehandalan, daya tanggap, jaminan mutu pelayanan, dan rasa empati terhadap pemustaka. Semua strategi tersebut dapat meningkatkan minat kunjungan pemustaka di perpustakaan UIN alauddin Makassar.

\section{b. Strategi dalam Sarana dan Prasarana pada UPT Perpustakaan UIN Alauddin Makassar}

Menurut Larasati (1991: 55) bahwa fungsi perpustakaan adalah berusaha memberikan pelayanan kepada lembaga pendidikan agar kegiatan belajar mengajar yang digariskan dalam kurikulum dapat berjalan dengan lancar. Sesuai dengan maksud itulah maka perpustakaan harus dapat menyediakan segala keperluan peralatan yang menunjang pengajaran yang dilaksanakan di lembaga pendidikan baik berupa bukubuku pegangan, buku-buku pelengkap dan sebagainya maupun bahan-bahan pengajaran lainnya seperti alat peraga. Mengenai keadaan gedung perpustakaan, yang harus diperhatikan adalah letak, jumlah ruangan dan tata ruangannya, yang perlu diperhatikan untuk mendirikan perpustakaan yaitu:

1) Letak perpustakaan berada di tengahtengah tempat berlangsungnya kegiatan lembaga pendidikan, sehingga mudah dicapai dari segala arah.

2) Konstruksi/keadaan gedung mampu menahan berat perabot dan isinya, tahan api dan tahan bakar, cukup banyak celah untuk memungkinkan 
memberi penerangan secara alamiah dan tanpa banyak tiang serta penyekat.

3) Pengaturan ruangan tergantung dari luas serta bentuk ruangan, dan demi kemudahan pelayanan, tetapi haruslah diperhatikan juga segi-segi arsistik, kenyamanan ventilasi, kesegaran ruangan dan keasriannya.

Dengan mengacu pada konsep di atas, maka hasil penelitian yang peneliti dapatkan dalam hasil wawancara dengan para informan adalah sebagai berikut:

Wawancara dengan kepala perpustakaan Universitas Islam Negeri Alauddin Makassar pada tanggal 11 Mei 2015, mengenai sarana dan prasarana di perpustakaan, beliau menyatakan bahwa:

"Mengenai sarana dan prasarana, kami menempati gedung sendiri dan terbilang strategis karena berada di tengah kampus, mudah dijangkau oleh mahasiswa dari berbagai fakultas dan jurusan. Rata-rata pengunjung perpustakaan setiap harinya sekitar 100-150 orang. Mulai dari mahasiswa program DIII, S1, S2 dan S3. Perpustakaan UIN Alauddin Makassar juga sering dikunjungi oleh mahasiswa maupun peneliti dari luar yang datang untuk mencari referensi atau sekedar berkunjung dan observasi. Adapun strategi perpustakaan terhadap peningkatan minat kunjung pemustaka ialah sebagai berikut: Penyediaan ruangan yang estetis dan nyaman, pengembangan koleksi perpustakaan, penyediaan wifi di dalam Perpustakaan, memberikan pelayanan berbasis pengguna, melengkapi sistem otomasi OPAC, serta memperbaharui perabot perpustakaan. "(Himayah, kepala Perpustakaan UIN Alauddin).

Berdasarkan hasil wawancara di atas, dapat diketahui bahwa ada beberapa poin strategi pengembangan sarana dan prasarana di perpustakaan UIN Alauddin
Makassar agar dapat meningkatkan minat kunjung pemustaka, yakni:

1) Penempatan gedung yang strategis

2) Penyediaan ruang yang estetis dan nyaman

3) Pengembangan koleksi perpustakaan

4) Penyediaan Wifi

5) Memberikan pelayanan berbasis pengguna

6) Menggunakan sistem otomasi Online Publik Acces Catalogue (OPAC)

7) Memperbaharui perabot perpustakaan

Strategi yang diterapkan di Perpustakaan UIN Alauddin Makassar terbukti dapat menarik minat kunjung pemustaka di perpustakaan. berdasarkan hasil wawancara dengan kepala perpustakaan tersebut di atas bahwa setiap harinya pengunjung perpustakaan sekitar 100-150 orang.

Selanjutnya, wawancara dengan koordinator bagian shelfing pada tanggal 11 Mei 2015, mengenai sarana dan prasarana di perpustakaan, beliau menyatakan bahwa:

"Untuk meningkatkan minat kunjung pemustaka, kami selalu mengupayakan penataan ruang yang nyaman, rak buku yang banyak sehingga memungkinkan untuk menyimpan buku dalam jumlah besar dan tidak saling berhimpitan sehingga mudah untuk menelusuri, meja dan kursi baca yang memiliki sekat sehingga pembaca tidak merasa terganggu dengan pengunjung disekitarnya, semua diatur dengan memperhatikan kenyamanan pengguna"

Selanjutnya, wawancara dengan koordinator bagian pengembangan koleksi mengenai strategi dalam hal sarana dan prasarana di perpustakaan Universitas Islam Negeri Alauddin Makassar pada tanggal 11 Mei 2015, beliau menyatakan bahwa: 
"Untuk pengembangan koleksi, kami senantiasa meningkatkan ketersediaan koleksi berupa buku umum, referensi, jurnal sesuai dengan kebutuhan pemustaka."

Selanjutnya, wawancara dengan koordinator bagian teknologi informasi mengenai strategi dalam hal sarana dan prasarana di perpustakaan Universitas Islam Negeri Alauddin Makassar pada tanggal 11 Mei 2015, beliau menyatakan bahwa:

"Kami menyediakan fasilitas informasi berupa buku dalam bentuk digital, majalah digital, kabinet gambar, lemari atau kabinet catalog, papan pengumuman, papan display, OPAC) yang lengkap dan memadai."

Berdasarkan hasil wawancara dengan para informan di atas, maka peneliti menarik kesimpulan sebagai berikut:

1) Letak gedung perpustakaan yang strategis dan mudah dijangkau oleh pemustak.

2) Penataan rak (rak buku, meja, kursi baca) strategis dan teratu

3) Kelengkapan koleksi (koleksi buku umum, referensi, jurnal) lengkap sesuai kebutuhan pemustaka.

4) Kelengkapan fasilitas (rak buku, rak majalah, kabinet gambar, lemari atau kabinet catalog, papan pengumuman, meja baca, kusi, papan display, OPAC) lengkap dan memadai.

5) Tersedia jaringan internet yang mendukung pemustaka untuk mengakses informasi.

\section{KESIMPULAN DAN SARAN}

\section{a. Kesimpulan}

Berdasarkan uraian-uraian yang telah dikemukakan sebelumnya, maka berikut ini penulis mengemukakan beberapa kesimpulan sebagai berikut :

1) Strategi Perpustakaan dalam meningkatkan minat kunjung pemustaka ditinjau dari aspek pelayanan pemustaka dititikberatkan pada kehandalan, daya tanggap, jaminan mutu pelayanan, dan rasa empati terhadap pemustaka.

2) Strategi Perpustakaan dalam meningkatkan minat kunjung pemustaka ditinjau dari aspek sarana dan prasarana :

a) Penempatan gedung perpustakaan yang strategis dan mudah dijangkau oleh pemustaka

b) Penataan rak (rak buku, meja, kursi baca) strategis dan teratur

c) Menyediakan koleksi (koleksi buku umum, referensi, jurnal) lengkap sesuai kebutuhan pemustaka.

d) Menyediakan fasilitas (rak buku, rak majalah, kabinet gambar, lemari atau kabinet catalog, papan pengumuman, meja baca, kusi, papan display, OPAC) lengkap dan memadai.

e) Menyediakan jaringan internet yang mendukung pemustaka untuk mengakses informasi.

\section{b. Saran}

Adapun saran dan masukan peneliti yaitu:

1) Perlunya pengawasan dan evaluasi terhadap seluruh aspek pelayanan sehingga pemustaka dapat memperoleh informasi yang maksimal dan pelayanan yang prima.

2) Perlunya penambahan dan penataan sarana dan prasarana setiap tahun sehingga kebutuhan pemustaka dapat terpenuhi. 
3) Perlu adanya penekanan dan pengarahan dari para dosen kepada mahasiswa untuk memanfaatkan perpustakaan secara maksimal dalam proses belajar-mengajar.

4) Pengelola perpustakaan hendaknya memaksimalkan kegiatan promosi perpustakaan melalui media-media promosi yang mudah diakses oleh pemustaka khususnya media elektronik dengan memanfaatkan fasilitas-fasilitas internet.

\section{DAFTAR PUSTAKA}

Arikunto, S. (1992). Prosedur Penelitian Suatu Pendekatan Praktis. Jakarta: Bulan Bintang.

Arikunto, S. (2000). Penelitian Suatu Pendekatan. Jakarta: Rineka Cipta.

Bafadal, I. (2008). Pengelolaan Perpustakaan Sekolah. Jakarta: Gramedia.

Burhan, B. (1997). Metode Penelitian Sosial. Yogyakarta: Gramedia.

Dahlan, W. (2006).Kemasan Perpustakaan Yang Menjual. Jakarta:Gramedia.

Darmono. (2001). Manajemen Dan Tata Kerja Perpustakaan Sekolah. Jakarta: Gramedia.

Depertemen Pendidikan dan Kebudayaan. (2008). Kamus Besar Bahasa Indonesia. Jakarta : Balai Pustaka.

Faozan, A. (2001). Total Quality Manajemen. Jakarta: Gramedia.

Frank, Jefkins, (1997). Periklanan. Jakarta: Erlangga.

Ibrahim, A. (2014). Pengantar Perpustakaan dan Kearsipan. Jakarta : Gunadarma Ilmu.

Kasmir. (2005). Etika Costumer Service. Jakarta: PT. Raja Grafindo Persada.

Lasa HS. (1995)). Jenis-jenis Pelayanan Informasi Perpustakaan. Yogyakarta: Kansius.

Malayu, H. S.P. (2008). Manajemen; Dasar, Pengertian, dan Masalah. Jakarta: PT.Bumi Aksara.
Mardalis, (1993). Metode Penelitian Suatu Pendekatan Proposal. Jakarta:Bumi Aksara.

Margono. (2000). Metodologi Penelitian Pendidikan. Jakarta: Rineka Cipta.

Marmoatmojo, K. (1999). Manajemen Pelayanan. Jakarta: Universitas Terbuka.

Milburga, L. et at. (1991). Membina Perpustakaan Sekolah. Yogyakarta: Kanisius.

Moenir, H.A.S. (1995). Manajemen Pelayanan Umum di Indonesia. Jakarta: Bumi Aksara.

Poerwadarminta. (1976). Kamus Umum Bahasa Indonesia. Jakarta: Balai Pustaka.

Qalyubi, S. (2007). Dasar-dasar Ilmu Perpustakaan dan Informasi. Yogyakarta: Jurusan Ilmu perpustakaan, Fakultas Adab.

Ratminto dan Winarsih. (2007). Pengelolaah Perpustakaan. Jakarta: Graha Ilmu.

Republik Indonesia. (2007). Undangundang Republik Indonesia Nomor 43 Tahun 2007 Tentang Perpustakaan. Jakarta: Perpustakaan Nasional RI.

Saifuddin, A. (2001). Relibialitas dan Validitas. Yogyakarta: pustaka belajar.

Soetminah. (1995).

Perpustakaan Kepustakawanan dan pustakawan. Yogyakarta: Kanisius.

Sudarsana, U dan Bastiano. (2010). Pembinaan Minat Baca. Jakarta: Universitas Terbuka.

Sudjana, N. (2002). Metode Statistik. Bandung: Tarsito.

Sugiyono. (2008). Metode Penelitian Pendidikan: Pendekatan Kuantitatif, Kualitatif, dan $R \mathcal{E} D$, Bandung: Alfabeta.

Sugiyono. (2009). Statistik Untuk Penelitian, Bandung: Alfabeta.

Sulistyo-Basuki. (1991). Pengantar Ilmu perpustakaan, Jakarta : Gramedia Pustaka Utama. 
Sulistyo-Basuki. (1992). Pengantar Ilmu perpustakaan, Jakarta: Gramedia Pustaka Utama.

Sulistyo-Basuki. (1993). Pengantar Ilmu perpustakaan, Jakarta: Gramedia Pustaka Utama

Sutarno NS. (1995). Pemahaman Individu II. Surakarta: UNS.

Sutarno NS. (2003). Perpustakaan dan Masyarakat. Jakarta: Sagung Seto.

Sutarno NS. (2008). Kamus Perpustakaan dan Informasi. Jakarta: Erlangga.

Sutarno NS.2006. Manajemen Perpustakaan : Suatu Pendekatan Praktis, Cet.II, Jakarta : Sagung Seto.

Suwarno, W. (2009). Psikologi Perpustakaan. Jakarta: Sagung Seto.

Tjiptono dan Diana. 2003.Total Quality Manajemen. Edisi Revisi. Yogyakarta: Andi.

Tjiptono, F. (1997). Manajemen Jasa. Yogyakarta:

Trimo, Soejono. (1985). Pedoman Pelayanan Perpustakaan. Bandung: Remaja Rosdakarya.

Usman, H. (2009). Metodologi Penelitian Sosial, Jakarta : Bumi Aksara.

Vincent, G. (2006). Toyal Quality Management. Jakarta: PT. Gramedia Pustaka Utama.

Yousda, A. (1993). Penilaian dan Statistik Pendidikan. Jakarta: Bumi Aksara. 